\title{
Changes in various metabolic parameters in blood and milk during experimental Escherichia coli mastitis for primiparous Holstein dairy cows during early lactation
}

Kasey M Moyes ${ }^{1 *}$, Torben Larsen², Peter Sørensen ${ }^{2}$ and Klaus L Ingvartsen ${ }^{2}$

\begin{abstract}
Background: The objective of this study was to characterize the changes in various metabolic parameters in blood and milk during IMI challenge with Escherichia coli (E. coli) for dairy cows during early lactation. Thirty, healthy primiparous Holstein cows were infused $(h=0)$ with $\sim 20-40$ cfu of live $E$. coli into one front mammary quarter at $\sim 4-6$ wk in lactation. Daily feed intake and milk yield were recorded. At $-12,0,3,6,12,18,24,36,48,60,72,96,108,120,132$, $144,156,168,180$ and $192 \mathrm{~h}$ relative to challenge rectal temperatures were recorded and quarter foremilk was collected for analysis of shedding of E. coli. Composite milk samples were collected at -180, -132, -84, -36, -12, 12, 24, 36, $48,60,72,84,96,132$ and $180 \mathrm{~h}$ relative to challenge $(h=0)$ and analyzed for lactate dehydrogenase $(\mathrm{LDH})$, somatic cell count, fat, protein, lactose, citrate, beta-hydroxybutyrate (BHBA), free glucose (fglu), and glucose-6-phosphate (G6P). Blood was collected at $-12,0,3,6,12,18,24,36,60,72,84,132$ and $180 \mathrm{~h}$ relative to challenge and analyzed for plasma non-esterified fatty acids (NEFA), BHBA and glucose concentration. A generalized linear mixed model was used to determine the effect of IMI challenge on metabolic responses of cows during early lactation.

Results: By 12 h, E. coli was recovered from challenged quarters and shedding continued through $72 \mathrm{~h}$. Rectal temperature peaked by $12 \mathrm{~h}$ post-challenge and returned to pre-challenge values by $36 \mathrm{~h}$ post-IMl challenge. Daily feed intake and milk yield decreased $(P<0.05)$ by 1 and $2 \mathrm{~d}$, respectively, after mastitis challenge. Plasma BHBA decreased $(12 \mathrm{~h} ; P<0.05)$ from $0.96 \pm 1.1$ at $0 \mathrm{~h}$ to $0.57 \pm 0.64 \mathrm{mmol} / \mathrm{L}$ by $18 \mathrm{~h}$ whereas concentration of plasma NEFA (18 $\mathrm{h}$ ) and glucose (24 h) were significantly greater, 11 and 27\%, respectively, after challenge. In milk, fglu, lactose, citrate, fat and protein yield were lower whereas yield of BHBA and G6P were higher after challenge when compared to pre-challenge values.

Conclusions: Changes in metabolites in blood and milk were most likely associated with drops in feed intake and milk yield. However, the early rise in plasma NEFA may also signify enhanced adipose tissue lipolysis. Lower concentrations of plasma BHBA may be attributed to an increase transfer into milk after IMI. Decreases in both milk lactose yield and \% after challenge may be partly attributed to reduced conversion of fglu to lactose. Rises in G6P yield and concentration in milk after challenge (24 h) may signify increased conversion of fglu to G6P. Results identify changes in various metabolic parameters in blood and milk after IMI challenge with E. coli in dairy cows that may partly explain the partitioning of nutrients and changes in milk components after IMI for cows during early lactation.
\end{abstract}

Keywords: Cow, Early lactation, Escherichia coli, Metabolism

\footnotetext{
*Correspondence: kmoyes@umd.edu

'Department of Animal and Avian Sciences, University of Maryland, 142 Animal Sciences Building, MD 20742-2311, 20910 College Park, MD, USA Full list of author information is available at the end of the article
} 


\section{Background}

During early lactation (i.e. 0-8 wk in milk), the homeorhetic mechanisms associated with hormonal changes, as well as changes in the nervous system and immune system, shift the partitioning of nutrients from peripheral tissues towards the synthesis of milk. This massive re-partition has been identified as a major contributor to the high risk of disease at this time [1]. Mastitis, an inflammation of the mammary gland, is the most costly of all diseases and occurs more frequently after parturition $[2,3]$. The innate immune response patterns to major mastitis-causing pathogens (e.g. E. coli, Streptococcus uberis and Staphylococcus aureus) have been well-documented [4-6] but the characterization of the metabolic responses in dairy cows during an IMI are not fully understood.

Most studies have focused on the effect of metabolic status on immune response for dairy cows $[1,7,8]$. During mastitis, the immunometabolic responses primarily focus on the transcription-level responses in liver and mammary tissue [9-11]. Previous work indicates that the ability of the liver to metabolize fatty acids is reduced and key genes associated with metabolic processes are down-regulated after intramammary E. coli challenge [12] as well as after intramammary endotoxin challenge [13]. Furthermore, changes in circulating non-esterified fatty acids (NEFA), beta-hydroxybutyrate (BHBA) and glucose, prior to decreases in feed intake and milk production, during an IMI in dairy cows have been reported [14-16]. To our knowledge, changes in free glucose (fglu) and glucose-6phosphate (G6P) in milk during mastitis in relation to changes in circulating metabolites and other milk components has not been elucidated. The mammary gland primarily relies on circulating glucose for the synthesis of lactose, a disaccharide composed of the monosaccharides D-glucose and D-galactose [17]. Other fates of glucose in the mammary gland include the conversion to G6P for the synthesis of galactose [18]. Characterizing the metabolic responses of fglu and G6P in relation to other metabolic components during inflammation may further elucidate the partitioning of nutrients and changes in milk composition that occur during mastitis. The objective of this study was to characterize the changes in various metabolic parameters in blood and milk during IMI with E. coli for dairy cows during early lactation.

\section{Methods}

The experiment was carried out at the cattle research facilities at Department of Animal Science, Aarhus University. Experimental procedures involving animals were approved by the Danish Animal Experiments Inspectorate and complied with the Danish Ministry of Justice Laws concerning animal experimentation and care of experimental animals.

\section{Animals, experimental design and sample collection}

Thirty primiparous Holstein cows at 4-6 wk in lactation were used for this study. Only healthy cows not treated for any clinical signs of disease before the study period were included. Details on animal housing, total mixed ration fed and refused, treatment, preparation and infusion of E. coli and clinical examinations have been previously described [19,20]. Briefly, eligible cows were considered healthy and free of mastitis-causing pathogens based on body temperature, white blood cell count, glutaraldehyde test, California Mastitis Test (Kruuse, Marslev, Denmark) and bacteriological examinations of aseptic quarter foremilk samples prior to the start of the study period. Using the portable DeLaval Cell Counter (DeLaval, Tumba, Sweden), the front quarter with the lowest somatic cell count (SCC; $<27,000$ cells/mL) was used for $E$. coli infusion.

Cows were housed and fed in individual straw-bedded tie-stalls, had free access to water, and were milked twice at 0600 and $1700 \mathrm{~h}$. Cows averaged $27.5 \pm 5.5 \mathrm{~kg}$ milk/d at the start of the trial. Cows were fed a standard total mixed ration for lactating cows ad libitum twice at 0800 and $1530 \mathrm{~h}$. Daily feed intake and milk yield were recorded throughout the study period. Orts were collected in the mornings $(\sim 0800 \mathrm{~h})$. To clarify, IMI challenge occurred after the afternoon milking, and therefore, $\mathrm{d}=0$ was calculated from milk yield and feed intakes from -36 to $-12 \mathrm{~h}$ prior to IMI challenge where $-12 \mathrm{~h}$ represents the morning relative to challenge.

All cows were infused with $\sim 20-40$ cfu of live $E$. coli (Danish field isolate k2bh2) into one front mammary quarter immediately following the afternoon milking $(\mathrm{h}=0)$. The IMI challenge was imposed in the same year (i.e. 2007) and stage of lactation but in 4 different blocks: May $(\mathrm{n}=8)$, June $(n=7)$, August $(n=8)$ and September $(n=8)$. Rectal temperature was recorded at $-12,0,3,6,12,18,24,48,60$, $72,84,96,108,120,132,144,156,168,180$ and 192 h relative to IMI challenge. Composite milk samples were collected relative to IMI challenge $(h=0)$ during the morning milking period at $-180,-132,-84,-36$, and $-12 \mathrm{~h}$, at each milking after challenge at $12,24,36,48,60,72,84,96 \mathrm{~h}$, and during the morning milking period at 132 and $180 \mathrm{~h}$. Aseptic quarter foremilk samples were collected from challenged quarters at $-12,0,3,6,12,18,24,48,60,84,96,108$, $120,132,144,156,168,180$ and $192 \mathrm{~h}$ relative to IMI challenge. One day prior to IMI challenge, sterile MicroRenathane polyvinyl catheters were inserted into the jugular vein and flushed with a sterile $0.9 \% \mathrm{NaCl}$ solution containing 50 IU Na-heparin (Loevens Kemiske Fabrik, Ballerup, Denmark). Blood was collected at $-12,0,3,6,12,18,24,36$, $60,84,132$ and $180 \mathrm{~h}$ relative to IMI challenge. For a subset of cows $(n=16)$, liver biopsies were collected at $-144,12$, 24 and $192 \mathrm{~h}$ relative to IMI challenge for gene expression profiling and results are reported elsewhere [12]; and a mammary biopsy was collected at 24 and $192 \mathrm{~h}$ relative to 
IMI challenge for gene expression analysis using a minimally invasive biopsy technique [19]. After the mammary biopsies had been collected (i.e. 24 and $192 \mathrm{~h}$ post-biopsy), cows were administered a prophylactic antibiotic treatment against infection with Gram-positive bacteria by intramuscular injection of $30 \mathrm{~mL}$ of Penovet ${ }^{\circ}$ vet (300,000 IE benzylpenicillinprocain/ml; Boehringer Ingelheim Danmark A/S, Copenhagen, Denmark). No other antibiotic therapy was administered after IMI challenge for all cows, regardless of biopsy.

\section{Sample analysis}

Composite milk samples were analyzed for fat, protein, lactose, citrate and SCC (cells/mL) using a CombiFoss 4000 (Foss Electric A/S, Hillerød, Denmark) and BHBA, lactate dehydrogenase (LDH), N-acetyl- $\beta$-D-glucosaminidase (NAGase) and alkaline phosphatase activity (ALP) were analyzed according to methods previously described [21-23]. Free glucose and G6P were analyzed by an enzymatic-fluorometric method as described by Larsen [24]. Quarter foremilk was analyzed for SCC and quantification of E. coli (cfu/mL) as previously described [19].

Plasma was harvested following centrifugation at 2,000 $\times g$ for $20 \mathrm{~min}$ at $4^{\circ} \mathrm{C}$ and stored at $-18^{\circ} \mathrm{C}$ until further analysis. All plasma components were analyzed for NEFA, BHBA and glucose using an autoanalyzer, ADVIA $1650^{\circ}$ Chemistry System (Siemens Medical Solution, Tarrytown, NY, USA) according to methods described by Bjerre-Harpøth et al. [21].

\section{Statistical analysis}

Plasma NEFA and BHBA were normalized by natural $\log (\mathbf{l n})$ transformation and SCC and shedding of E. coli were $\log _{10}$ transformed for statistical analyses. Yields for all milk components were calculated at each milking. Data were analyzed via a generalized linear mixed model using the MIXED procedure of SAS, version 9.3 [25] with the repeated measure of time (i.e. hour) relative to

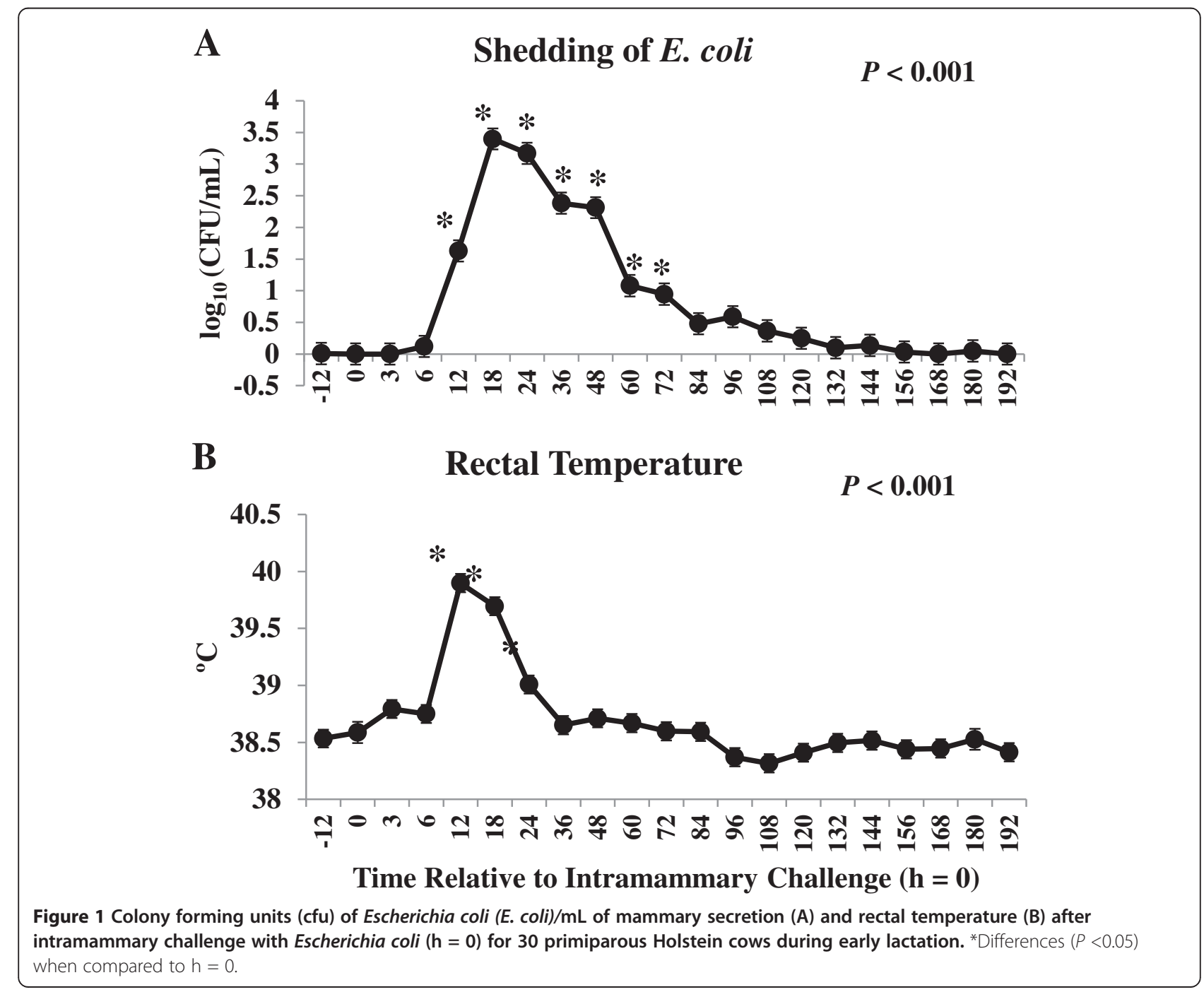


IMI challenge $(h=0)$. Using the MIXED procedure of SAS, combined biopsy had no effect $(P<0.05)$ on any of the metabolic parameters in blood and milk for this study and was, therefore, left out of the final model. The random effect of cow within block was used as the error term in the REPEATED statement with compound symmetry (CS) as the covariance structure. The model was used to determine the effect of IMI challenge on metabolic and immune responses in blood and milk for cows in early lactation. The class variables included cow, block and time relative to IMI challenge. Degrees of freedom were estimated with the Kenward-Roger specification in the model statements. Separation of least square means (LSM) for significant effects was accomplished using the Tukey's option within the MIXED procedure of SAS. Statistical differences were declared as significant and highly significant at $P<0.05$ and $P<0.01$, respectively. Trends towards significance are discussed at $P<0.10$. Plasma NEFA and BHBA were back-transformed for presentation in figures.

\section{Results and discussion}

Indicators of infection and immune response

The bacterial counts of E. coli (A) and rectal temperature (B) relative to IMI challenge are shown in Figure 1. By $12 \mathrm{~h}, E$. coli was recovered from challenged quarters and shedding continued through $72 \mathrm{~h}$ similar to those of others $[26,27]$. Rectal temperature returned to pre-challenge values by $36 \mathrm{~h}$ post-IMI challenge as observed by Scaletti and Harmon [27]. These findings are consistent with signs of experimental E. coli mastitis and confirmed the model system.

Composite milk LDH (A), SCC (B), NAGase (C) and ALP (D) concentrations were greater after IMI challenge with $E$. coli (Figure 2). During an IMI challenge, a cascade of changes occur including increased LDH, ALP and NAGase activity in milk associated with infiltrating neutrophils and resident macrophages $[28,29]$. These indigenous enzymes are accurate real-time indicators for detecting mastitis on-farm when compared to composite SCC or bacterial culture [28-30].

\section{Cow-level and metabolic responses}

Changes in daily feed intake (as fed; A) and milk yield (B) relative to IMI challenge are shown in Figure 3. To clarify, $\mathrm{d}=0$ reflects the daily feed intake and milk yield from the $24 \mathrm{~h}$ period prior to IMI challenge (i.e. -36 to $-12 \mathrm{~h}$ relative to IMI challenge). Day $=1$ reflects -12 to $12 \mathrm{~h}$ post-IMI challenge. Daily milk yield decreased $23 \%$ from $d=0$ to $d=1$ and $36 \%$ by $d=2$ whereas feed intake was not significantly reduced until $2 \mathrm{~d}$ post-IMI challenge from $29.7 \mathrm{~kg}$ at $\mathrm{d}=0$ to $21.7 \mathrm{~kg}$ by $\mathrm{d}=2$. Feed intake and milk yield returned to pre-challenge values by 3 and $4 \mathrm{~d}$ post-IMI challenge, respectively. As lactation progressed, feed intake continued to increase as normally observed during early lactation [31]. Decreases in feed intake and milk yield have been previously shown

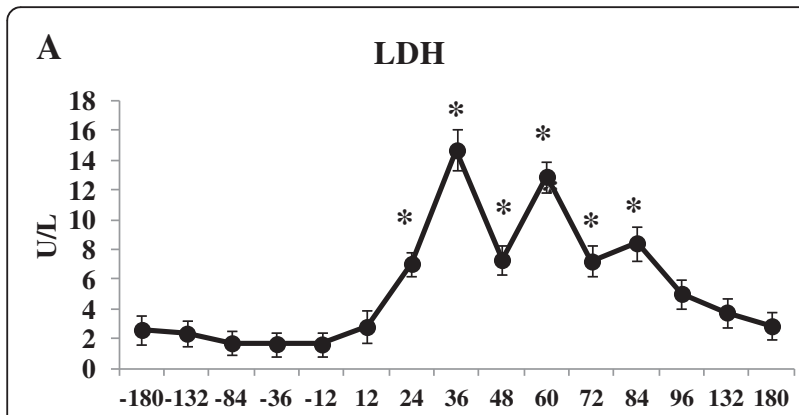

C

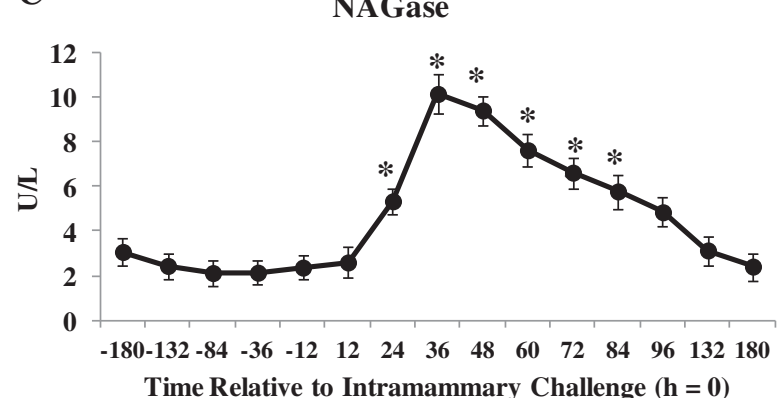

B

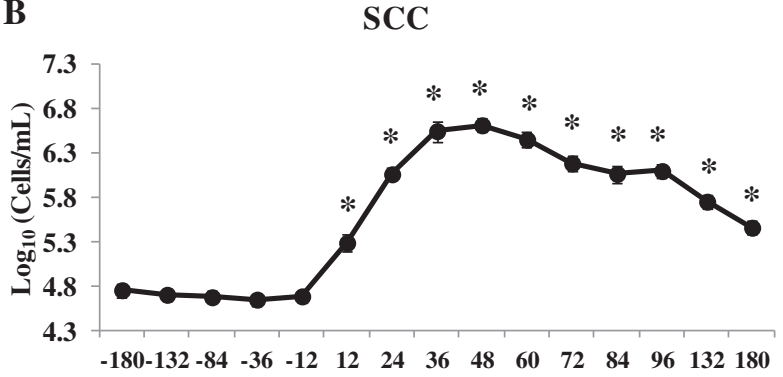

D

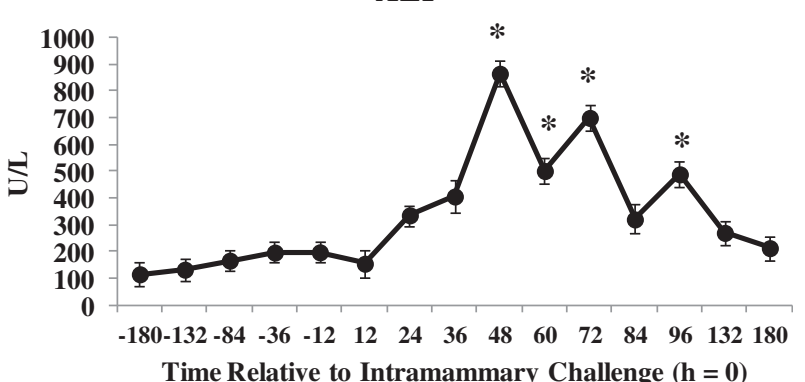

Figure 2 Composite milk concentrations of lactate dehydrogenase (LDH; A), somatic cell count (SCC; B), N-acetyl- $\beta$-D-glucosaminidase (NAGase; C) and alkaline phosphatase (ALP; D) at time points relative to intramammary challenge with Escherichia coli $(\mathrm{h}=0)$ in 30 primiparous Holstein cows during early lactation. *Differences $(P<0.05)$ when compared to $h=0$. 


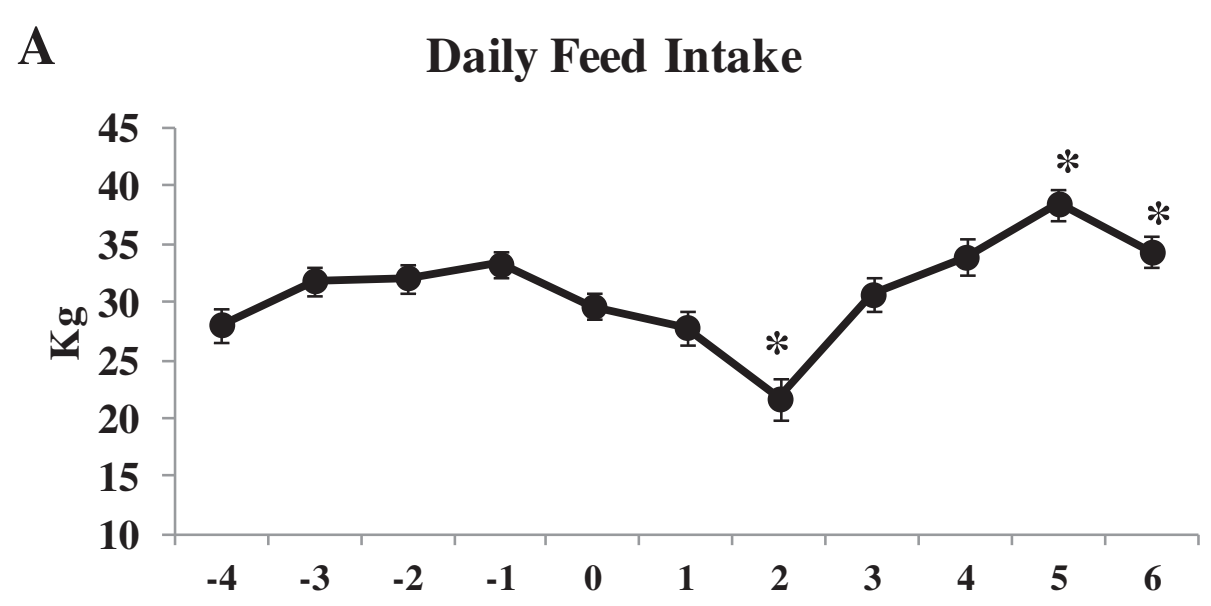

B

Daily Milk Yield

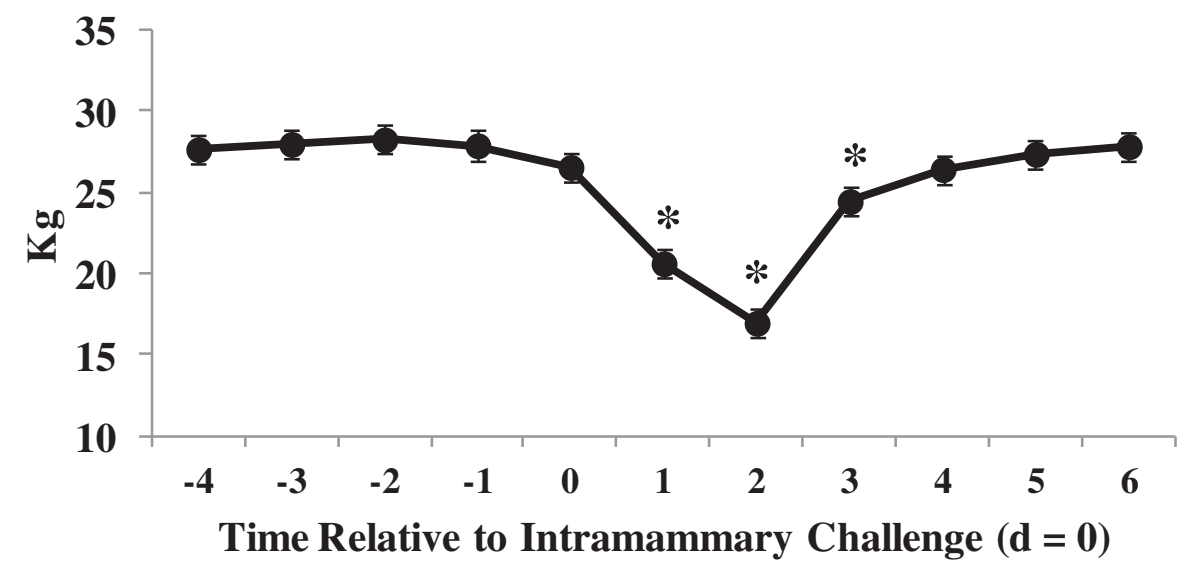

Figure 3 Daily feed intake (as fed; A) and daily milk yield (B) for 30 primiparous Holstein cows during early lactation relative to intramammary challenge with Escherichia coli $(\mathbf{h}=\mathbf{0})$. *Differences $(P<0.05)$ when compared to $d=0$ ( $d=0$ includes -36 to $-12 \mathrm{~h}$ relative to challenge).

for cows experimentally challenged with $E$. coli during early lactation [27]. Multiple local and systemic factors, i.e. production of cytokines and the changing hormonal environment, contribute to reduced feed intake and milk production observed during an IMI [32] and most likely explain the majority of variation in blood and milk metabolites for this study.

Changes in concentration of plasma NEFA (A), glucose $(\mathrm{AB})$ and BHBA $(\mathrm{C})$ relative to IMI challenge are shown in Figure 4. Blood samples collected prior to the morning feeding included -12, 12, 36, 60, 84, 132 and 180 h relative to IMI challenge. Plasma NEFA increased $11 \%$ by $18 \mathrm{~h}$, after the morning feeding, but no other time points differed from pre-challenge values throughout the study period. Although changes in plasma NEFA may be primarily attributed to changes in feed intake, increases in plasma NEFA may also be associated with enhanced lipolysis in adipose tissue, regardless of changes in feed intake, which has been proposed to be the primary source of elevated NEFA in blood during inflammation [33]. Steiger et al. [34] showed increased NEFA in blood following a prolonged low-dose intravenous (IV) lipopolysaccharide (LPS) infusion in non-lactating heifers. Similar results were reported after intramammary challenge with LPS for both primiparous and multiparous cows at 7 days in milk [14] and after IV infusion of LPS for multiparous cows in midlactation [16]. These results contradict those of Waldron et al. [15] where plasma NEFA decreased after intramammary LPS infusion for multiparous cows in early lactation as well as Moyes et al. [7] where no change in plasma NEFA was observed after IMI challenge with Streptococcus uberis for multiparous cows in mid-lactation. Our results, and those of others, indicate that plasma NEFA increase, regardless of stage of lactation or parity, in response to both live bacteria reported here (i.e. E. coli) and LPS administered either intramammary [16] or IV [34].

Plasma glucose was greater at 24 and $36 \mathrm{~h}$ when compared to $-12 \mathrm{~h}$ (Figure 4B) where plasma glucose was 


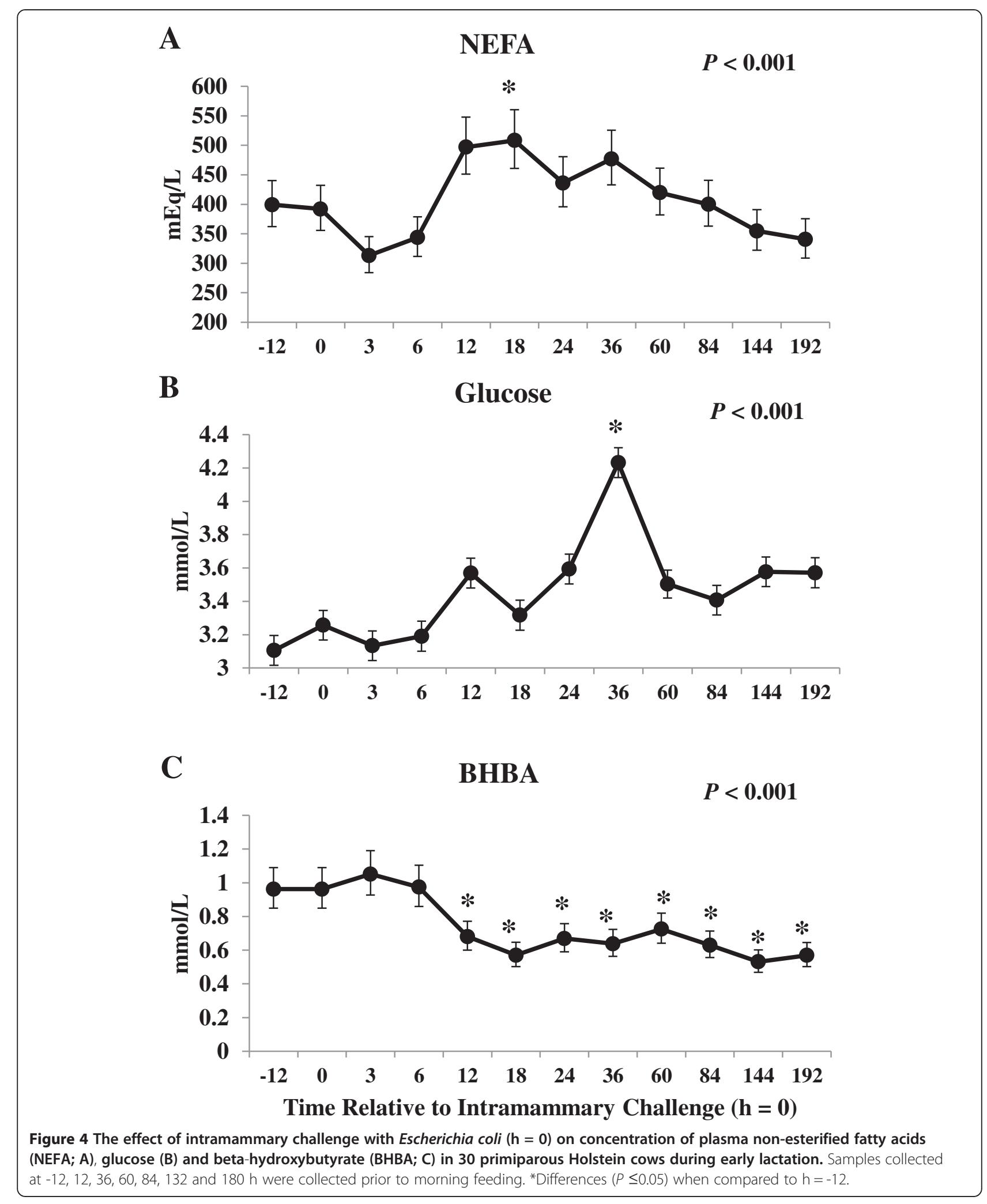

$26.6 \%$ greater at 36 when compared to $-12 \mathrm{~h}$ relative to IMI challenge. Increases in plasma glucose are primarily attributed to changes in feed intake and reduced demand for lactose synthesis in the mammary gland in response to IMI challenge. However, Steiger et al. [34] observed increases in plasma glucose after IV LPS infusion in 


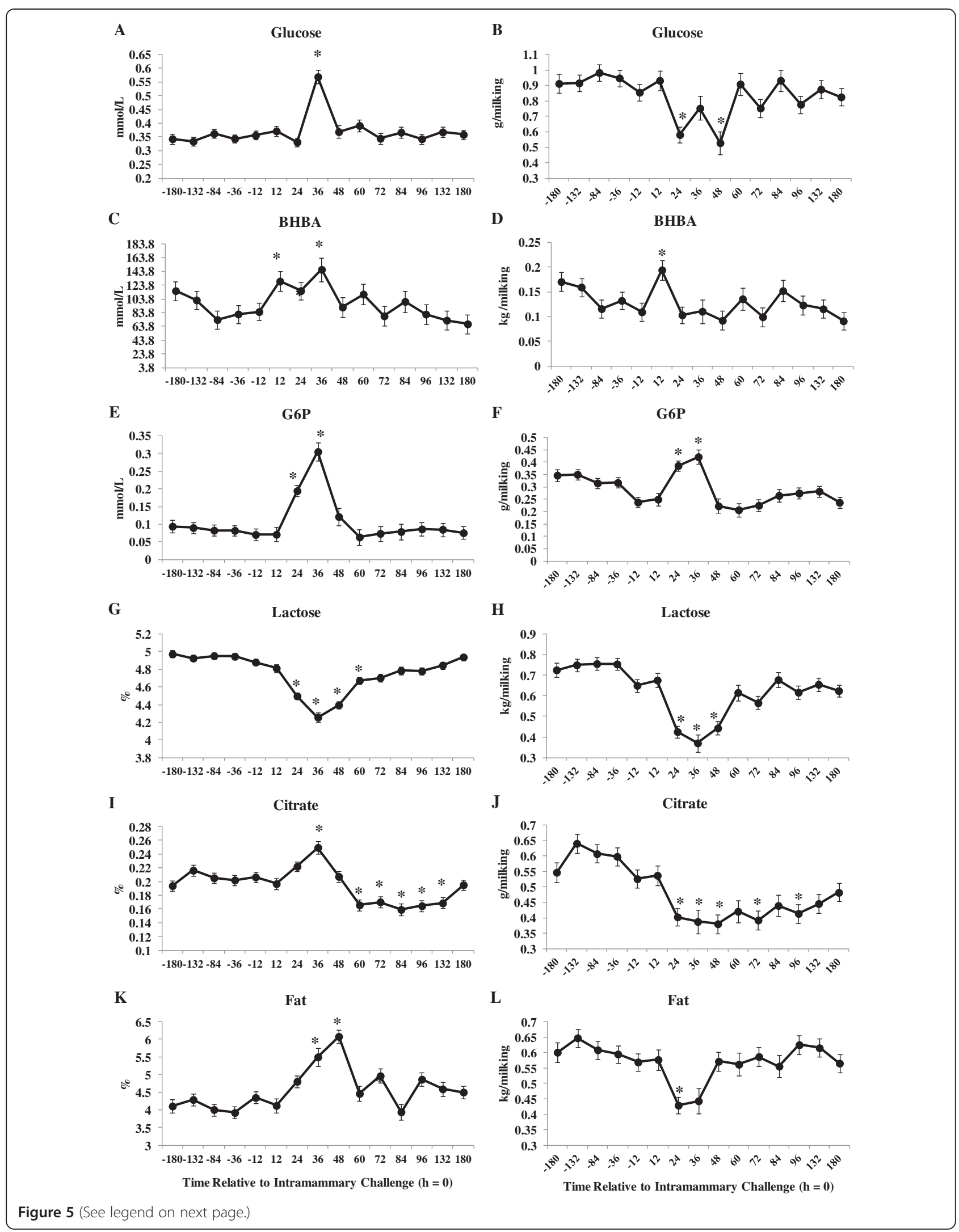


(See figure on previous page.)

Figure 5 The effect of intramammary challenge with Escherichia coli $(\mathrm{h}=0)$ on concentration and yield of milk glucose ( $\mathrm{A}$ and $\mathrm{B}$, respectively), BHBA (C and D, respectively), glucose-6-phosphate (G6P; $E$ and $F$, respectively), lactose (G and $H$, respectively), citrate (I and J, respectively) and fat ( $\mathrm{K}$ and $\mathrm{L}$, respectively) in $\mathbf{3 0}$ primiparous Holstein cows during early lactation. Samples collected at -12, 12, $36,60,84,132$ and $180 \mathrm{~h}$ were collected prior to morning feeding. * Differences $(P \leq 0.05)$ when compared to $\mathrm{h}=-12$.

non-lactating heifers indicating that hyperglycemia is independent of changes in milk production.

The mechanisms regulating glucose homeostasis during IMI are unclear and the primary theories are 1) changes in feed intake, 2) increased circulating glucocorticoids observed during infection [16,35], 3) decreased lactose synthesis in the mammary gland, 4) increased hepatic lactate recycling via the Cori cycle $[16,36], 5)$ increased glycogenolysis in peripheral tissues [34,37] and/or 6) increased hepatic gluconeogenesis [36]. Increases in glucocorticoids observed after infection are associated with increased adipose tissue lipolysis, increased hepatic gluconeogenesis and inhibition of insulin sensitivity in skeletal muscle [38]. Changes in plasma glucocorticoid concentrations were not assessed for this study and the contribution to changes in plasma glucose are unknown. Hyperglycemia has been reported in sheep [36] and in non-lactating dairy heifers [34] after inflammation and therefore decreases in milk lactose synthesis may not be the only factor explaining increases in plasma glucose at this time. Furthermore, glycogen stores are largely depleted during early lactation [39] and increased glycogenolysis unlikely explains changes in glucose supply based on transcriptional responses in liver for this study [12]. A down-regulation of key genes associated with hepatic gluconeogenesis was observed in liver tissue for this study by $24 \mathrm{~h}$ post-IMI challenge [12] including phosphoenolpyruvate carboxykinase 1 (PCK1; -8.2-fold change versus pre-IMI challenge) and glucose-6-phosphatase (G6PC; -1.7-fold change). However, an up-regulation of both lactate dehydrogenase A ( $L D H A ; 1.2$-fold change) and $\mathrm{B}(L D H B ; 1.1$-fold-change) were observed in liver at $24 \mathrm{~h}$ post-IMI challenge. Both $L D H A$ and $L D H B$ code for functional $\mathrm{LDH}$, the enzyme responsible for the reversible conversion of lactate to pyruvate, and supports the theory of a potential increase in lactate recycling via the Cori cycle during IMI challenge [16,36].

Plasma BHBA decreased by $12 \mathrm{~h}$ post-IMI challenge when compared to pre-challenge levels (Figure 4C). Other studies have reported decreased circulating concentrations of BHBA during an intramammary challenge with LPS for lactating dairy cows [14,15,34]. During inflammation, decreases in BHBA in blood are a consequence of either 1) increased blood glucose; 2) changes in BHBA supply via reduced rumen motility [37,40]; 3) impairment of hepatic ketogenesis [34,41]; or 4) a combination of the above. Transcriptional profiling of liver tissue indicated a downregulation of genes associated with hepatic ketogenesis [12] including 3-hydroxy-3-methylglutaryl-CoA synthase
1 (HMGCS1; -2.5-fold change) and HMGCS2 (-28.0-fold change) and may partly explain lower plasma BHBA after IMI challenge for this study. Concentration of milk BHBA were elevated at 12 and $36 \mathrm{~h}$ post-IMI challenge and returned to pre-challenge levels by $48 \mathrm{~h}$ (Figure 5C). Furthermore, yield of milk BHBA increased at $12 \mathrm{~h}$ post-IMI challenge (Figure 5D) and indicates that the lower BHBA observed in blood is due to an increase transfer into milk after IMI challenge.

Changes in fglu, BHBA, G6P, lactose, citrate and fat in milk relative to IMI challenge are shown in Figure 5. In addition, milk protein \% decreased during IMI challenge (data not shown). Yield of fglu, lactose, fat, protein (data not shown) and citrate were lower whereas yield of G6P and BHBA were higher after IMI challenge. Decreases in milk component yield are mostly explained by lower milk yield ( $-36 \%$ by $d=2$ post-challenge) observed when compared to the pre-challenge period. Transcriptomic-level profiling of mammary quarters at $24 \mathrm{~h}$ post-IMI challenge revealed no changes in key genes associated with glucose metabolism and utilization between challenged and unchallenged quarters [19] and therefore cannot support changes in major milk components discussed in this study. Concentration of citrate was greater by $36 \mathrm{~h}$ post-IMI challenge followed by a decrease in citrate to concentrations below those observed at $\mathrm{h}=-12$ (Figure 5I) whereas citrate yield was lower by $24 \mathrm{~h}$ post-IMI challenge (Figure 5J). Concentration of milk citrate was also shown to decrease in LPS challenged quarters from lactating dairy cows [42]. Milk citrate, a marker of mitochondrial metabolism in the mammary gland [43], induces the ferric citrate transport system and is competing with lactoferrin for iron [42]. Lactoferrin contributes to host defense by binding iron thereby reducing availability of iron to invading bacteria [44] and lower yield of citrate may indicate an increase in the iron-binding capacity of bovine lactoferrin [45].

Concentration and yield of milk lactose decreased by $24 \mathrm{~h}$ after IMI challenge and returned to pre-challenge levels by $72 \mathrm{~h}$ (Figures $5 \mathrm{G}$ and $\mathrm{H}$, respectively). Lactose is the major osmole in milk and decreases in milk yield and the synthesis milk components, such as lactose and protein, most likely explain the majority of changes in lactose during IMI challenge. However, lower milk lactose yield may be attributed to lower yield of fglu (Figure $5 \mathrm{~B}$ where the yield of fglu (Figure 5B) was lower at 24 and $48 \mathrm{~h}$ when compared to $-12 \mathrm{~h}$ relative to IMI challenge. Both concentration and yield of G6P (Figure 5E and F, 
respectively) rose after IMI challenge. Elevated levels of G6P by $24 \mathrm{~h}$ post-IMI challenge may signify increased conversion of fglu from lactose synthesis and towards the synthesis of G6P. However, this is not supported by the transcription-level profiling in mammary tissue at 24-h after IMI challenge [19]. Glucose-6-phosphate may serve as a substrate for the pentose phosphate pathway for the production of reducing equivalents used for several anabolic processes [24].

\section{Conclusions}

Although drops in feed intake and milk yield are major contributors to changes in the metabolic response in blood and milk, the early rise in plasma NEFA during IMI challenge with $E$. coli may be partly attributed to increased adipose tissue lipolysis. Lower plasma BHBA may be associated with increase transfer into milk. We are the first to characterize changes in fglu and G6P in milk during IMI challenge. Lower yield of milk lactose may be attributed to lower yield of fglu. Higher G6P yield after IMI challenge may signify increased conversion of fglu to G6P. Results identify the metabolic response of various parameters in blood and milk and characterize the changes in fglu and G6P after IMI challenge with $E$. coli for cows in early lactation that may partly explain the partitioning of nutrients and changes in milk components in dairy cows with mastitis during early lactation. Future research is needed to determine how i.e. stage of lactation, parity, bacteria alter these metabolic changes that may help identify risk factors for the development, severity and duration of mastitis for dairy cows during lactation.

\section{Competing interests}

The authors declare that they have no competing interests.

\section{Authors' contributions \\ KMM performed statistical analysis and interpretation and writing of the manuscript. TL provided financial support, analyzed all blood and milk parameters and contributed to the interpretation and writing of the manuscript. PS contributed financial support, design of the experimental model, acquisition of data and contributed to the interpretation and writing of the manuscript. KLI contributed financial support and contributed to the interpretation and writing of the manuscript. All authors read and approved the final manuscript.}

\section{Acknowledgements \\ The authors would like to thank and acknowledge the staff at the Department of Animal Science's Dairy Cattle facility, Aarhus University, and Martin Bjerring, Jens Clausen, and Hanne Møller Purup for their excellent technical assistance and analytical skills. This study was partly funded by the European Commission, within the 6th Framework Program (contract No. FOOD-CT-2006-016250) and the BIOSENS project granted by the Danish Ministry of Food, Agriculture and Fisheries (Innovations Law), Lattec I/S, the Danish Cattle Association, and the Faculty of Science and Technology, Aarhus University.}

\section{Author details}

'Department of Animal and Avian Sciences, University of Maryland, 142 Animal Sciences Building, MD 20742-2311, 20910 College Park, MD, USA. ${ }^{2}$ Department of Animal Science, Faculty of Science and Technology, Aarhus University, Tjele 8830, Denmark.
Received: 28 May 2014 Accepted: 10 October 2014

Published: 17 October 2014

\section{References}

1. Ingvartsen $\mathrm{KL}$, Moyes KM: Nutrition, immune function and health of dairy cattle. Animal 2013, 7(Suppl 1):112-122.

2. Bar D, Tauer LW, Bennett G, Gonzalez RN, Hertl JA, Schukken YH, Schulte HF, Welcome FL, Grohn YT: The cost of generic clinical mastitis in dairy cows as estimated by using dynamic programming. J Dairy Sci 2008, 91:2205-2214.

3. Green MJ, Green LE, Medley GF, Schukken YH, Bradley AJ: Influence of dry period bacterial intramammary infection on clinical mastitis in dairy cows. J Dairy Sci 2002, 85:2589-2599.

4. Schukken YH, Gunther J, Fitzpatrick J, Fontaine MC, Goetze L, Holst O, Leigh J, Petzl W, Schuberth HJ, Sipka A, Smith DG, Quesnell R, Watts J, Yancey R, Zerbe H, Gurjar A, Zadoks RN, Seyfert HM, members of the Pfizer mastitis research consortium: Host-response patterns of intramammary infections in dairy cows. Vet Immunol Immunopathol 2011, 144:270-289.

5. Ballou MA: Inflammation: Role in the etiology and pathophysiology of clinical mastitis in dairy cows. J Anim Sci 2011, 10:1466-1478.

6. Bannerman DD, Paape MJ, Goff JP, Kimura K, Lippolis JD, Hope JC: Innate immune response to intramammary infection with Serratia marcescens and Streptococcus uberis. Vet Res 2004, 35:681-700.

7. Moyes KM, Drackley JK, Salak-Johnson JL, Morin DE, Hope JC, Loor JJ: Dietary-induced negative energy balance has minimal effects on innate immunity during a Streptococcus uberis mastitis challenge in dairy cows during mid-lactation. J Dairy Sci 2009, 92:4301-4316.

8. Zarrin M, Wellnitz O, Van Dorland HA, Bruckmaier RM: Induced hyperketonemia affects the mammary immune response during lipopolysaccharide challenge in dairy cows. J Dairy Sci 2014, 97:330-339.

9. Loor JJ, Moyes KM, Bionaz M: Functional adaptations of the transcriptome to mastitis-causing pathogens: the mammary gland and beyond. J Mammary Gland Biol Neoplasia 2011, 16:305-322.

10. Moyes KM, Drackley JK, Morin DE, Bionaz M, Rodriguez-Zas SL, Everts RE, Lewin HA, Loor JJ: Gene network and pathway analysis of bovine mammary tissue challenged with Streptococcus uberis reveals induction of cell proliferation and inhibition of PPARgamma signaling as potential mechanism for the negative relationships between immune response and lipid metabolism. BMC Genomics 2009, 10:542-571.

11. Vels $L$, Rontved $C M$, Bjerring $M$, Ingvartsen $K L$ : Cytokine and acute phase protein gene expression in repeated liver biopsies of dairy cows with a lipopolysaccharide-induced mastitis. J Dairy Sci 2009, 92:922-934.

12. Jorgensen $H B$, Buitenhuis $B$, Rontved $C M$, Jiang $L$, Ingvartsen $K L$, Sorensen $P$ : Transcriptional profiling of the bovine hepatic response to experimentally induced E. coli mastitis. Physiol Genomics 2012, 44:595-606.

13. Jiang L, Sorensen P, Rontved C, Vels L, Ingvartsen KL: Gene expression profiling of liver from dairy cows treated intra-mammary with lipopolysaccharide. BMC Genomics 2008, 9:443.

14. Graugnard DE, Moyes KM, Trevisi E, Khan MJ, Keisler D, Drackley JK, Bertoni G, Loor JJ: Liver lipid content and inflammometabolic indices in peripartal dairy cows are altered in response to prepartal energy intake and postpartal intramammary inflammatory challenge. J Dairy Sci 2013, 96:918-935.

15. Waldron MR, Kulick AE, Bell AW, Overton TR: Acute experimental mastitis is not causal toward the development of energy-related metabolic disorders in early postpartum dairy cows. J Dairy Sci 2006, 89:596-610.

16. Waldron MR, Nishida T, Nonnecke BJ, Overton TR: Effect of lipopolysaccharide on indices of peripheral and hepatic metabolism in lactating cows. J Dairy Sci 2003, 86:3447-3459.

17. Annison EF, Linzell JL, West CE: Mammary and whole animal metabolism of glucose and fatty acids in fasting lactating goats. J Physiol 1968, 197:445-459.

18. Scott RA, Bauman DE, Clark JH: Cellular gluconeogenesis by lactating bovine mammary tissue. J Dairy Sci 1976, 50:50-56.

19. Buitenhuis B, Rontved CM, Edwards SM, Ingvartsen KL, Sorensen P: In depth analysis of genes and pathways of the mammary gland involved in the pathogenesis of bovine Escherichia coli-mastitis. BMC Genomics 2011, 12:130-140.

20. Fogsgaard KK, Rontved CM, Sorensen P, Herskin MS: Sickness behavior in dairy cows during Escherichia coli mastitis. J Dairy Sci 2012, 95:630-638.

21. Bjerre-Harpøth V, Friggens NC, Thorup VM, Larsen T, Damgaard BM, Ingvartsen KL, Moyes KM: Metabolic and production profiles of dairy cows 
in response to decreased nutrient density to increase physiological imbalance at different stages of lactation. J Dairy Sci 2012, 95:2362-2380.

22. Larsen T: Determination of lactate dehydrogenase (LDH) activity in milk by a fluorometric assay. J Dairy Res 2005, 72:209-216.

23. Larsen T, Nielsen NI: Fluorometric determination of beta-hydroxybutyrate in milk and blood plasma. J Dairy Sci 2005, 88:2004-2009.

24. Larsen T: Fluorometric determination of free glucose and glucose-6phosphate in cow milk and other opaque matrices. J Food Chem 2014, Accepted.

25. SAS User's Guide: Statistics V93E. Cary, NC: SAS Inst., Inc; 2012.

26. Ma JL, Zhu YH, Zhang L, Zhuge ZY, Liu PQ, Yan XD, Gao HS, Wang JF: Serum concentration and mRNA expression in milk somatic cells of toll-like receptor 2, toll-like receptor 4 , and cytokines in dairy cows following intramammary inoculation with Escherichia coli. J Dairy Sci 2011, 94:5903-5912.

27. Scaletti RW, Harmon RJ: Effect of dietary copper source on response to coliform mastitis in dairy cows. J Dairy Sci 2012, 95:654-662.

28. Babaei H, Mansouri-Najand L, Molaei MM, Kheradmand A, Sharifan M: Assessment of lactate dehydrogenase, alkaline phosphatase and aspartate aminotransferase activities in cow's milk as an indicator of subclinical mastitis. Vet Res Commun 2007, 31:419-425.

29. Chagunda MG, Larsen T, Bjerring M, Ingvartsen KL: L-lactate dehydrogenase and $\mathrm{N}$-acetyl-beta-D-glucosaminidase activities in bovine milk as indicators of non-specific mastitis. J Dairy Res 2006, 73:431-440.

30. Friggens NC, Chagunda MG, Bjerring M, Ridder C, Hojsgaard S, Larsen T: Estimating degree of mastitis from time-series measurements in milk: a test of a model based on lactate dehydrogenase measurements. J Dairy Sci 2007, 90:5415-5427.

31. Janovick NA, Drackley JK: Prepartum dietary management of energy intake affects postpartum intake and lactation performance by primiparous and multiparous Holstein cows. J Dairy Sci 2010, 93:3086-3102.

32. Ingvartsen $\mathrm{KL}$, Andersen JB: Integration of metabolism and intake regulation: a review focusing on periparturient animals. J Dairy Sci 2000 83:1573-1597.

33. $\mathrm{Zu} \mathrm{L}, \mathrm{He} J$, Jiang $H, X u$ C, Pu S, Xu G: Bacterial endotoxin stimulates adipose lipolysis via toll-like receptor 4 and extracellular signal-regulated kinase pathway. J Biol Chem 2009, 284:5915-5926.

34. Steiger M, Senn M, Altreuther G, Werling D, Sutter F, Kreuzer M, Langhans W: Effect of a prolonged low-dose lipopolysaccharide infusion on feed intake and metabolism in heifers. J Anim Sci 1999, 77:2523-2532.

35. Jamieson AM, Yu S, Annicelli CH, Medzhitov R: Influenza virus-induced glucocorticoids compromise innate host defense against a secondary bacterial infection. Cell Host Microbe 2010, 7:103-114.

36. Naylor JM, Kronfeld DS: In vivo studies of hypoglycemia and lactic acidosis in endotoxic shock. Am J Physiol 1985, 248:E309-E316.

37. Lohuis JA, Verheijden JH, Burvenich C, Van Miert AS: Pathophysiological effects of endotoxins in ruminants. 2. Metabolic aspects. Vet Q 1988, 10:117-125.

38. Park SY, Bae JH, Cho YS: Cortisone induces insulin resistance in $\mathrm{C} 2 \mathrm{C} 12$ myotubes through activation of 11 beta-hydroxysteroid dehydrogenase 1 and autocrinal regulation. Cell Biochem Funct 2014, 32:249-257.

39. Drackley JK: Biology of dairy cows during the transition period: the final frontier? J Dairy Sci 1999, 82:2259-2273.

40. Huhtanen $\mathrm{P}$, Miettinen $\mathrm{H}$, Ylinen M: Effect of increasing ruminal butyrate on milk yield and blood constituents in dairy cows fed a grass silage-based diet. J Dairy Sci 1993, 76:1114-1124.

41. Kaminski MV Jr, Neufeld HA, Pace JG: Effect of inflammatory and noninflammatory stress on plasma ketone bodies and free fatty acids and on glucagon and insulin in peripheral and portal blood. Inflammation 1979, 3:289-294.

42. Hyvönen $P$, Haarahiltunen $T$, Lehtolainen $T$, Heikkinen J, Isomäki R, Pyörälä S: Concentrations of bovine lactoferrin and citrate in milk during experimental endotoxin mastitis in early- versus late-lactating dairy cows. J Dairy Res 2010, 77:474-480.
43. Faulkner A, Peaker M: Reviews of the progress of dairy science: secretion of citrate into milk. J Dairy Res 1982, 49:159-169.

44. Brock JH: The physiology of lactoferrin. Biochem Cell Biol 2002, 80:1-6.

45. Bishop JG, Schanbacher FL, Ferguson LC, Smith KL: In vitro growth inhibition of mastitis-causing coliform bacteria by bovine apo-lactoferrin and reversal of inhibition by citrate and high concentrations of apo-lactoferin. Infect Immun 1976, 14:911-918.

doi:10.1186/2049-1891-5-47

Cite this article as: Moyes et al:: Changes in various metabolic parameters in blood and milk during experimental Escherichia coli mastitis for primiparous Holstein dairy cows during early lactation. Journal of Animal Science and Biotechnology 2014 5:47.

\section{Submit your next manuscript to BioMed Central and take full advantage of:}

- Convenient online submission

- Thorough peer review

- No space constraints or color figure charges

- Immediate publication on acceptance

- Inclusion in PubMed, CAS, Scopus and Google Scholar

- Research which is freely available for redistribution

Submit your manuscript at www.biomedcentral.com/submit
C Biomed Central 